\title{
Cell-Type-Specific Expression of Catecholamine Transporters in the Rat Brain
}

\author{
Dominique Lorang, ${ }^{1,3}$ Susan G. Amara, ${ }^{1,2}$ and Richard B. Simerly ${ }^{2,3}$ \\ 1 Vollum Institute and ${ }^{2}$ Program in Neuroscience, Oregon Health Sciences University, Portland, Oregon 97201, and \\ ${ }^{3}$ Division of Neuroscience, Oregon Regional Primate Research Center, Beaverton, Oregon 97006
}

The dopamine transporter (DAT) and norepinephrine transporter (NET) terminate catecholaminergic neurotransmission at synapses by high-affinity sodium-dependent reuptake into presynaptic terminals, and are the initial sites of action for drugs of abuse and antidepressants. In the present study, we used in situ hybridization combined with immunohistochemistry to study the distribution of DAT and NET mRNA in the adult rat brain. Cells were first immunolabeled with antisera directed against one of the catecholaminesynthetic enzymes, tyrosine hydroxylase (TH), dopamine- $\beta$ hydroxylase (DBH), or phenylethanolamine- $\mathrm{N}$-methyltransferase (PNMT), in order to identify dopaminergic, noradrenergic, or epinephrine-containing cells. The immunolabeled cells were subsequently assayed for their ability to express catecholamine transporter mRNAs by in situ hybridization using either a rat DAT or NET cRNA probe. All dopaminergic cell groups of the mesencephalon contained high levels of DAT mRNA but only the A12 and A13 dopaminergic cell groups of the diencephalon appear to express detectable levels of DAT. All norepinephrine-containing cell bodies in the brainstem (locus coeruleus and lateral tegmentum) appear to express NET mRNA. In contrast, epinephrine-containing cell bodies of the brainstem do not appear to express NET mRNA, which raises the possibility that epinephrine may utilize a transporter that is distinct from the other bioactive amines, or may act as an endocrine regulator that does not require rapid reuptake mechanisms. Moreover, the cell-typespecific expression of catecholamine transporters suggests that DAT and NET gene expression may be closely linked to cellular mechanisms that specify transmitter phenotype.

The termination of neurotransmission is a critical component of neural signaling and depends on the rapid removal of neurotransmitters from the synaptic cleft. Pharmacological evidence indicates that the action of monoamines at the synapse is terminated predominantly by rapid reuptake into presynaptic nerve endings via neurotransmitter-specific,

\footnotetext{
Sept. 27, 1993; revised Jan. 19, 1994; accepted Feb. 16, 1994.

We thank Anne Carr for her expert technical assistance and Anna Seledkov for preparation of the manuscript. This work was supported by NIH Grants NS26723 and RR00163, the Theordore and Vada Stanley Foundation, and the Alfred P. Sloan Foundation (R.B.S.); and NIDA Grant DA07595 and the Hitchings Award from Burroughs-Wellcome (S.G.A.). D.L. is supported by NIH Research Fellowship Award DA0554202. This is publication 1908 of the Oregon Regional Primate Research Center.

Correspondence should be addressed to Dominique Lorang, Ph.D., Oregon Regional Primate Research Center, 505 N.W. 185th Avenue, Beaverton, Oregon 97006.

Copyright (c) 1994 Society for Neuroscience $0270-6474 / 94 / 144903-12 \$ 05.00 / 0$
}

high-affinity, $\mathrm{Na}^{+}$-dependent membrane transporter proteins. The CDNAs encoding distinct transporter proteins for the monoamines dopamine, norepinephrine, and serotonin have been cloned, expressed, and characterized in a variety of heterologous systems (Blakely et al., 1991; Giros et al., 1991; Hoffman et al., 1991; Kilty et al., 1991; Pacholczyk et al., 1991; Shimada et al., 1991; Usdin et al., 1991). Although the monoamine transporters share a high degree of sequence homology, they are distinguished by their monoamine substrate specificities and by their differential sensitivities to a wide spectrum of transport antagonists. For example, pharmacological agents that potently inhibit norepinephrine and serotonin transport, such as desmethylimipramine and citalopram, have little effect on the activity of the dopamine transporter (Javitch et al., 1983). Correspondingly, certain inhibitors of dopamine uptake, such as the GBR family of compounds and mazindol, pharmacologically distinguish the dopamine transporter from other monoamine transporters (Janowsky et al., 1986; Anderson, 1987, 1989). Thus, in addition to playing an essential role in synaptic transmission, neurotransmitter transporters are the sites of action for a wide range of drugs with demonstrated therapeutic potential.

[Key words: in situ hybridization, immunohistochemistry, catecholamines, transporters, mesencephalon, diencephaIon, brainstem, tyrosine hydroxylase, dopamine- $\beta$-hydroxylase, mRNA, substantia nigra, ventral tegmental area, locus coeruleus]

The cxpression pattcrn of catccholaminc transporters generally corresponds to the central distribution of catecholamine neurons. Two RNA species that selectively hybridize to a human norepinephrine transporter (NET) probe, of approximately 5.8 kilobases $(\mathrm{kb})$ and $3.6 \mathrm{~kb}$ in size, have been detected in the PNS and CNS (Pacholczyk et al., 1991). The expression of the 5.8 $\mathrm{kb}$ RNA species in the rat CNS appears to be restricted to the brainstem, which contains all of the central noradrenergic cell bodies, and is therefore likely to encode a neuronal norepinephrine transporter. In contrast, Northern blot analysis of dopamine transporter (DAT) mRNA identified a single RNA species in the rat midbrain (Shimada et al., 1991; Usdin et al., 1991).

The distribution of neurons that express catecholamine transporter mRNAs has not been described in detail. Preliminary results of in situ hybridization studies indicate that the distribution of DAT mRNA corresponds quite closely to that of dopaminergic neurons (Kilty et al., 1991; Shimada et al., 1991, 
1992; Bannon et al., 1992), which are restricted to the diencephalon and mesencephalon of the CNS. Diencephalic dopaminergic cell groups include the incertohypothalamic pathways from the zona incerta and periventricular zone of the hypothalamus, and the tuberohypophyseal dopaminergic neurons in the arcuate nucleus that regulate hormone secretion from the anterior pituitary. In the mesencephalon, dopaminergic neurons are largely localized to the substantia nigra and ventral tegmental area and the projections of these cell groups form the nigrostriatal and the mesocorticolimbic dopamine pathways (Carter and Fibiger, 1977; Fallon and Moore, 1978; Swanson, 1982). Neurons in the pars compacta of the substantia nigra and medial parts of the ventral tegmental area send projections to the striatum and neocortex, and this nigrostriatal pathway plays a critical role in sensorimotor integration, maintenance of posture, and movement initiation (see Swanson, 1982).

Other projections arising from the substantia nigra and ventral tegmental area ascend through the medial forebrain bundle to innervate widespread regions of the forebrain, including the nucleus accumbens, olfactory tubercle, amygdala, lateral septum, anterior limbic cortex, dorsal hippocampus, and entorhinal area (Björklund and Lindvall, 1984, 1986). This mesocorticolimbic pathway is especially important in modulating affective and motivational responses, and disturbances of this pathway may contribute to specific symptoms of depression, mania, and schizophrenia (Iversen, 1973, 1977; Snyder, 1973; Crow, 1982; Bloom et al., 1989). Moreover, stimulation of the mesocorticolimbic dopaminergic neurons is implicated in cocaine reinforcement, arousal, and amphetamine psychosis, which may be due to increased availability of synaptic dopamine resulting from inhibition of transporter-mediated dopamine reuptake (Snyder, 1972; Ritz et al., 1987). The DAT has therefore been proposed as the primary binding site mediating the addictive effects of cocaine, although additional physiological actions of the drug may reflect its ability to inhibit the other monoamine transporters (Cooper et al., 1991).

Preliminary findings suggest that NET mRNA expression is largely restricted to regions of the brain containing noradrenergic cell bodies. Relative to the dopaminergic neurons, the central distribution of noradrenergic neurons is somewhat more restricted, with the majority of cells residing in the locus coeruleus and the lateral tegmental nucleus of the brainstem reticular formation, yet these cells influence activity in widely distributed regions throughout the brain and spinal cord (Björklund and Lindvall, 1986). The locus coeruleus sends projections throughout most of the forebrain, the cerebellum, and lateral column of the spinal cord, and it is the sole source of noradrenaline fibers in the isocortex. The lateral tegmental adrenergic neurons send projections to the basal forebrain, hypothalamus, and the brainstem reticular formation, as well as to the majority of brainstem motor nuclei (Moore and Bloom, 1979; Moore and Card, 1984).

The localization of DAT and NET gene expression to specific catecholaminergic cell bodies is of great clinical interest for several reasons. First, the neurons that express these transporters are important targets for the action of tricyclic and other antidepressants and drugs of abuse such as cocaine and amphetamines. Second, a number of clinical disorders result from perturbations in central catecholaminergic pathways, indicating that an altered expression of DAT and NET in specific dopaminergic or noradrenergic cell bodies may influence the expression of the disease state. For example, neuropsychiatric disorders such as schizophrenia and mania are characterized by an overactivity of ascending dopaminergic projections which are important in modulating the impact of emotions and motivation on behavior (Matthysee, 1973; Meltzer and Stahl, 1976; Meltzer, 1980; Seeman, 1980, 1987), and movement disorders such as Parkinson's disease are characterized by a deficiency of dopaminc in pathways critical to normal movement and sensorimotor integration (Hornykiewicz, 1973). Since DAT is an important regulator of dopaminergic neurotransmission in these pathways, an altered expression of the transporter may be critical in the etiology of such dopamine-related disorders. Similarly, since NET is an important target for a number of tricyclic antidepressants, it may be involved in the complex series of synaptic and neurochemical alterations that ultimately results in alleviating depression (Glowinski and Axelrod, 1964).

Since DAT and NET have similar substrate specificities and overlapping pharmacological profiles, the definition of their pathway-specific expression pattern will be important for interpreting the functional significance of catecholamine transporters in regulating synaptic efficacy. As a first step toward addressing these issues, we have used in situ hybridization to evaluate the detailed distribution of neurons that express DAT and NET mRNA in the rat brain. In addition, in situ hybridization was combined with immunohistochemistry to define the cell-type specificity of DAT and NET gene expression in catecholaminergic neurons.

\section{Materials and Methods}

\section{Cell cullure techniques}

PC1 2 pheochromocytoma tumor cells were obtained from ATCC and cultured in Dulbecco's Modified Eagle's Medium (DME) supplemented with $5 \%$ horse serum, $5 \%$ fetal calf serum, $100 \mathrm{U} / \mathrm{ml}$ penicillin $\mathrm{G}$ sodium, and $100 \mu \mathrm{g} / \mathrm{ml}$ streptomycin sulfate. Cells were maintained at $37^{\circ} \mathrm{C}$ in a humidified $5 \% \mathrm{CO}_{2}$ incubator.

\section{Cloning of rat NET CDNA fragment}

Degenerate oligonucleotide primers, corresponding to regions of high sequence identity between the human norepinephrine and rat GABA transporters, located between putative transmembrane domains II and VI of the human NET sequence, were generated with the following sequences: sense, CCGCTCGAGAAGAACGG(C/T)GG(C/T)GG(C/ $\mathrm{T}) \mathrm{GC}(\mathrm{C} / \mathrm{T}) \mathrm{TTC}(\mathrm{C} / \mathrm{T}) \mathrm{T}(\mathrm{G} / \mathrm{A}) \mathrm{AT}(\mathrm{C} / \mathrm{T}) \mathrm{CC}(\mathrm{A} / \mathrm{G}) \mathrm{TA}$; and antisensc, GCTCTAGAAA(G/A)AAGATCTG(G/A)GT(G/T)GC(G/A)GC(G/ A)TC(G/A/C)A(G/T)CCA. Oligonucleotide primers and cDNA prepared from rat $\mathrm{PC} 12$ tumor cells, which endogenously express NET, were used in polymerase chain reactions (PCR) performed with Taq polymerase (Promega) for 25 cycles at $94^{\circ} \mathrm{C}(1 \mathrm{~min}), 50^{\circ} \mathrm{C}(2 \mathrm{~min})$, and $72^{\circ} \mathrm{C}$ ( $\left.3 \mathrm{~min}\right)$, with the final extension lengthened to $10 \mathrm{~min}$. A single PCR product corresponding to a $660 \mathrm{bp}$ fragment was produced, excised from the gel, and subcloned into the vector Bluescript SKII( - ) (Stratagene). Sequencing of the $660 \mathrm{bp}$ DNA fragment was performed by dideoxy chain termination using the Sequenase 2.0 kit (U.S. Biochemical Corporation) with the vector primers $\mathrm{T} 7$ and $\mathrm{T} 3$. This $660 \mathrm{bp}$ PCR fragment shares greater than $90 \%$ sequence identity with the corresponding human NET sequence.

\section{Combined immunohistochemistry and in situ hybridization}

Tissue preparation. Adult male Sprague-Dawley rats were deeply anesthetized with tribromoethanol and, after a brief saline rinse, each animal was perfused transcardially with ice-cold $4 \%$ paraformaldehyde in 0.1 M borate buffer at $\mathrm{pH} 9.5$, after which the brains were quickly removed and postfixed overnight at $4^{\circ} \mathrm{C}$ in the same fixative containing $20 \%$ sucrose. Twenty-micrometer-thick frozen sections through the brain, typically at a frequency of one in four, were collected in chilled $0.02 \mathrm{M}$ potassium phosphate-buffered saline (KPBS) that contained $0.25 \%$ paraformaldehyde ( $\mathrm{pH} 7.4)$.

Antibodies and staining. The immunohistochemical methods used in this study essentially follow those described by Watts and Swanson 
(1989). Free-floating sections were washed in 0.02 м KPBS and preincubated in a blocking buffer solution ( $2 \%$ BSA, 5 mM DTT, $0.06 \%$ SDS, $0.625 \mathrm{U}$ RNasin in $0.02 \mathrm{M} \mathrm{KPBS}$ ) overnight at $4^{\circ} \mathrm{C}$. Sections were washed in KPBS, incubated in antisera raised in rabbit (Eugene Tech) at a dilution of 1:16,000 for tyrosine hydroxylase (TH), 1:4000 for dopamine- $\beta$-hydroxylase (DBH), and 1:4000 for phenylethanolamine- $N$ methyltransferase (PNMT) for $72 \mathrm{hr}$ at $4^{\circ} \mathrm{C}$, and stained using a Vectastain Elite $\mathrm{ABC}$ kit (Vector) with diaminobenzidine as the substrate. The stained sections were mounted onto gelatin and poly-L-lysine-coated microscope slides. Following a $30 \mathrm{~min}$ proteinase $\mathrm{K}$ digestion $(10 \mu \mathrm{g})$ $\mathrm{ml}$ at $\left.37^{\circ} \mathrm{C}\right)$ and acetylation $(0.0025 \%$ at room temperature $)$, the sections were dehydrated in ascending alcohols and dried under vacuum for at least $2 \mathrm{hr}$.

In situ hybridization. The hybridization protocol used in the present study essentially follows that of Cox et al. (1984). T3 polymerase was used to transcribe ${ }^{35} \mathrm{~S}$-labeled antisense cRNA probes from a $660 \mathrm{bp}$ XhoI-Xbal fragment of plasmid pDAT that is complementary to part of the coding region of rat DAT mRNA (Kilty et al., 1991) and is contained in plasmid Bluescript SKII(-). Probes complementary to NET $m$ RNA were synthesized using T3 polymerase to transcribe a 660 bp insert that corresponds to the rat NET cDNA amplification product, as described above. The radiolabeled cRNA probes were column purified (Nick-column, Pharmacia) and multiple $100 \mu \mathrm{l}$ fractions eluted from the column were counted using a scintillation counter. The purified cRNA probe was heated at $65^{\circ} \mathrm{C}$ for $5 \mathrm{~min}$ with $500 \mu \mathrm{g} / \mathrm{ml}$ yeast tRNA and $50 \mu \mathrm{M}$ dithiothreitol (DTT) in water before being diluted to an activity of $1.5 \times 10^{6} \mathrm{dpm} / \mathrm{ml}$ with hybridization buffer containing $50 \%$ formamide, $0.25 \mathrm{~m}$ sodium chloride, $1 \times$ Denhardt's solution, and $10 \%$ dextran sulfate. This hybridization solution was pipetted onto the sections ( $70 \mu \mathrm{l} / \mathrm{slide}$ ), covered with a glass coverslip, and sealed with DPX (Gallard and Schleisenger) before incubation for $20 \mathrm{hr}$ at $60^{\circ} \mathrm{C}$. Following hybridization, the slides were washed four times ( $10 \mathrm{~min}$ each) in $4 \times$ SSC prior to RNase digestion $\left(20 \mu \mathrm{g} / \mathrm{ml}\right.$ for $30 \mathrm{~min}$ at $\left.37^{\circ} \mathrm{C}\right)$, and rinsed at room temperature, in decreasing concentrations of SSC that contained $1 \mathrm{~mm}$ DDT $(2 \times, 1 \times, 0.5 \times ; 10 \mathrm{~min}$ each $)$, to a final stringency of $0.1 \times$ SSC at $75^{\circ} \mathrm{C}$ for $30 \mathrm{~min}$. After dehydration in increasing alcohols the sections were exposed to Dupont Cronex $x$-ray films for $4 \mathrm{~d}$ before being dipped in NTB-2 liquid emulsion. The dipped autoradiograms were developed $14 \mathrm{~d}$ later with Kodak D-19 developer. Those sections not previously immunolabeled were counterstained with thionin through the emulsion. Possible chemographic artifacts were evaluated by processing immunostained sections not processed for in situ hybridization for autoradiography. No evidence of positive chemography was observed and the distribution and density of labeled neurons was similar in doubly labeled tissue as in tissue that was processed for in situ hybridization alone.

Several control experiments were carried out to test the specificity of both the hybridization method and the DAT and NET probes. First, sections were incubated as described above with hybridization solution containing $1.5 \times 10^{6} \mathrm{dpm} / \mathrm{ml}$ of "sense-strand" (not complementary to DAT and NET mRNA) probe synthesized using T7 polymerase to transcribe the coding strand of the DNA insert. Second, hybridization was also attempted on sections that had been pretreated with RNase $\left(10 \mu \mathrm{g} / \mathrm{ml}\right.$ for $30 \mathrm{~min}$ at $\left.37^{\circ} \mathrm{C}\right)$. Posthybridization treatments were then carried out on these control sections as described above to a final stringency of $0.1 \times$ SSC at $75^{\circ} \mathrm{C}$. In addition, the thermal stability of the DAT and NET RNA:RNA hybrids was assessed by taking seven adjacent series of sections, through the midbrain for DAT CRNA probe or the brainstem for NET cRNA probe, that had been hybridized as described above and rinsing one series each in $0.1 \times \mathrm{SSC}$ at $65^{\circ} \mathrm{C}, 75^{\circ} \mathrm{C}$, $80^{\circ} \mathrm{C}, 85^{\circ} \mathrm{C}, 90^{\circ} \mathrm{C}, 95^{\circ} \mathrm{C}$, and $100^{\circ} \mathrm{C}$. Finally, the detailed distribution of DAT and NET mRNA-containing cells throughout the brain was compared with those of mRNA-containing cells labeled using probes directed towards different neuronal messages, including those encoding proopiomelanocortin, preprocholecystokinin, preprotachykinin, and the androgen, mineralocorticoid, and glucocorticoid receptors. The distribution of labeled neurons was charted onto a standard series of drawings that correspond to the adult rat brain maps presented by Swanson (1992).

\section{Northern blot analysis}

PolyA ${ }^{+}$-enriched RNA was isolated from tissues using fast-track RNA preparation (Promega). One hundred nanograms of rat DAT DNA, or rat NET DNA, werc cxcised from pBlucscript with XhoI or XbaI and Xhol, respectively, and labeled with ${ }^{32} \mathrm{P}-\mathrm{dCTP}$ (50 $\mu \mathrm{Ci}$; Amersham) using random-primed oligonucleotide primers (Boehringer-Mannheim). One microgram of polyA ${ }^{+}$RNA was separated on a $2 \%$ agarose gel and transferred to zeta probe nylon membrane. The full-length rat DNA probes were hybridized to the membrane for $24 \mathrm{hr}$ at $42^{\circ} \mathrm{C}$ in $50 \%$ formamide, $5 \times$ SSPE, $1 \times$ Denhardt's solution, $10 \%$ dextran sulfate, $1 \%$ sodium dodecyl sulfate (SDS), and $500 \mu \mathrm{g} / \mathrm{ml}$ salmon sperm DNA. The blot was washed at $65^{\circ} \mathrm{C}$ for $1 \mathrm{hr}$ at $0.1 \times$ SSPE and $0.1 \%$ SDS and exposed against film for $48 \mathrm{hr}$.

\section{Results}

A fragment of the rat homolog of the human NET cDNA (Pacholczyk et al., 1991) was isolated from a rat PC12 cDNA library PCR using degenerate oligonucleotides as described in Materials and Methods. Northern blot analysis using this PCR fragment as a specific probe revealed the localization of two rat NET mRNAs (5.8 and $3.6 \mathrm{~kb}$ in length) expressed in PC12 tumor cells, rat brainstem, and rat adrenal gland (Fig. $1 A$ ), yet in each tissue, the larger $5.8 \mathrm{~kb}$ species gave a stronger hybridization signal. Only the $3.6 \mathrm{~kb}$ species was detected in forebrain, midbrain, brainstem, and cerebellum RNA. These results are in agrecment with previous studics that used a human NET cDNA probe to demonstrate the presence of transcripts of the same size in RNA derived from rat brainstem and adrenal gland (Pacholcyzk et al., 1991), as well as in RNA from placental brush border cells (Ramamoorthy et al., 1993). Using the rat DAT fragment as a probe in a Northern blot assay of RNA isolated from a variety of rat brain regions, a single RNA species ( $3.8 \mathrm{~kb}$ in length) was detected in RNA from the midbrain region (Fig. $1 B$ ), as described previously (Shimada et al., 1991; Usdin et al., 1991).

The regional distribution of DAT and NET mRNA expression in rat brain was determined by in situ hybridization histochemistry. Both DAT and NET mRNA-containing cells were distributed in accordance with the known distribution of catecholaminergic cell bodies in the adult rat brain, with each transporter showing a unique distribution pattern. In emulsion-coated sections, DAT and NET mRNA-containing cells were identified by clusters of silver grains over single cells. Labeled cells were defined as those with labeling that exceeded a $99.9 \%$ Poisson labeling criterion (Arnold, 1980). Both DAT and NET mRNA appear to be exclusively expressed in neurons since labeled cells examined at high magnification met the classic morphological criteria for neurons as they appear in Nissl-stained material, and very few silver grains were observed over fiber tracts. This labeling appeared specific because silver grains were not observed over cells when sections were treated with RNase A prior to hybridization with an antisense cRNA probe, or when sections were hybridized with a sense-strand probe. In addition, thermal stability of RNA:RNA hybrids demonstrated that the labeling achieved by in situ hybridization is specific because a significant reduction in the density of the silver grains over labeled neurons was seen only when the temperature of the final posthybridization wash exceeded $90^{\circ} \mathrm{C}$, whercas background labeling decreased linearly with increasing temperature. The specificity of the labeling observed is also supported by the unique and nonoverlapping distribution patterns found for each catecholamine transporter. Thus, DAT mRNA labeling was detected only in regions of the brain that contain dopaminergic cell bodies, and NET cRNA labeling was found only in regions of the brainstem known to contain norepinephrine cell bodies.

The expression pattern within the three major classes of catecholamine cells was studied by combining immunohistochemistry with in situ hybridization. Catecholaminergic cell bodies 
A.
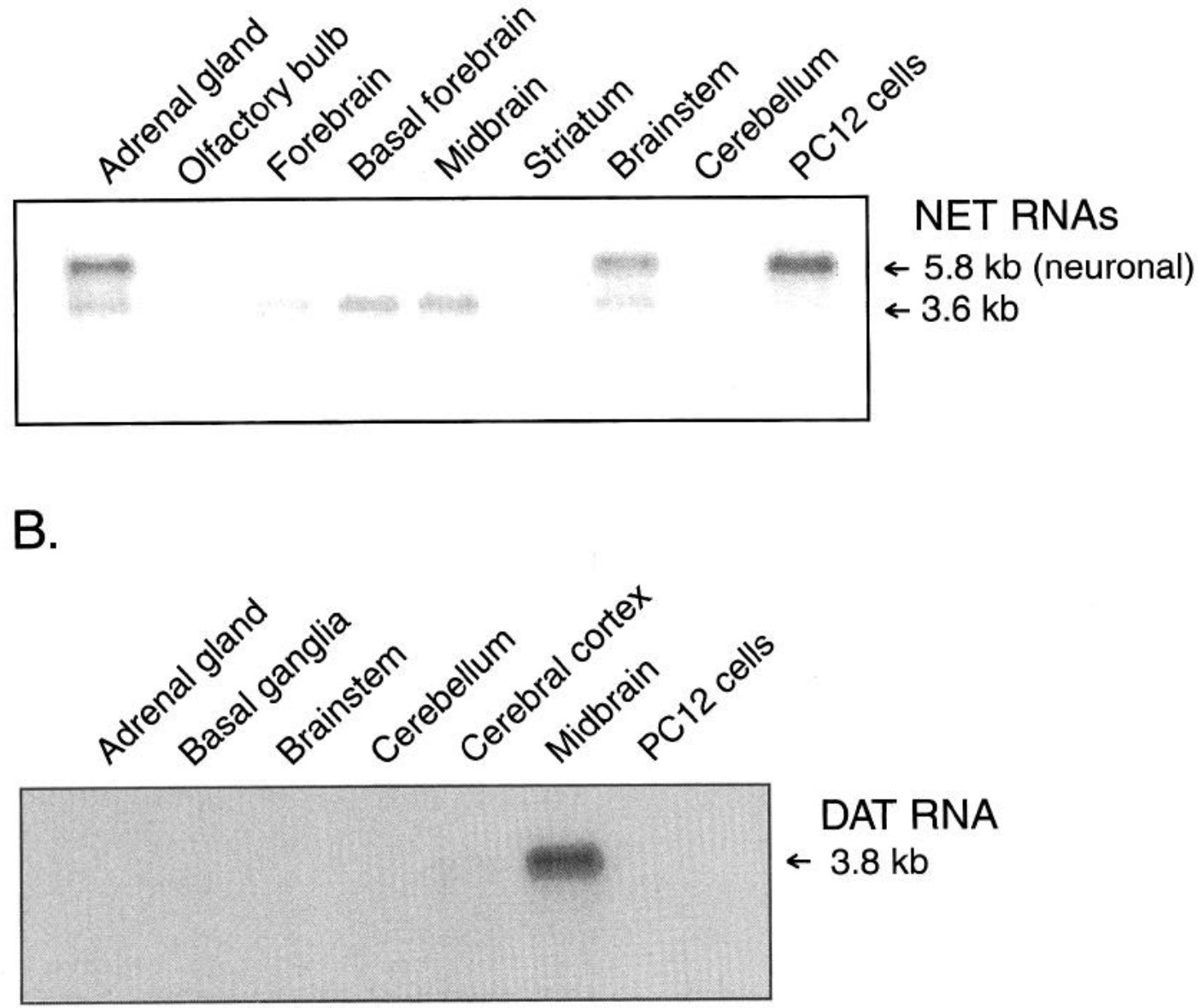

Figure 1. NET and DAT mRNA: Northern blot analysis of NET $(A)$ and DAT $(B)$ RNA localization in rat pheochromocytoma cells (PC12 cells) and various rat brain regions.

in the rat brain were identified using antibodies directed against the monoamine synthetic enzymes TH, DBH, and PNMT. In accordance with previous studies, cell groups were classified as dopaminergic if they showed TH immunoreactivity, but no DBH or PNMT immunoreactivity. Cells were considered to be noradrenergic if they showed DBH immunoreactivity and were PNMT negative, and adrenergic if cells were immunolabeled with PNMT antisera. After immunolabeling, cells were then processed for in situ hybridization. Although processing sections for immunohistochemistry prior to in situ hybridization reduced the density of silver grains over cells by $30-50 \%$ relative to sections processed for in situ hybridization alone, immunostaining did not significantly alter the overall distribution of DAT or NET mRNA-containing cells identified in doubly labeled material. Figures 2 and 3 depict the distribution of TH-, DBH-, and PNMT-immunoreactive cells, DAT and NET mRNA-containing cells, and doubly labeled cells.

\section{Distribution of cells containing catecholamine transporter $m R N A$}

Mesencephalic dopaminergic cells. The most intensely labeled DAT mRNA-containing neurons were found in the substantia nigra and the ventral tegmental area, which correspond to the A8, A9, and A10 catecholaminergic cell groups (Fig. 4A). The zona compacta and zona lateralis of the substantia nigra (A9 cell group) contained the greatest density of labeled cells, but DAT mRNA-containing cells were also found in the zona reticulata of the substantia nigra and in the region of the A8 cell group caudal to the substantia nigra. Analysis of tissue processed for immunohistochemistry and in situ hybridization confirmed that greater than $90 \%$ of the TH-immunoreactive cells in the zona compacta and zona lateralis of the substantia nigra, and throughout the ventral tegmental area (A10 cell group), were intensely labeled for DAT mRNA (Fig. $4 B-D$ ). Similarly, approximately $90 \%$ of the $\mathrm{TH}$-positive cells in the zona reticulata and the A8 group were also heavily labeled for DAT mRNA. In contrast, only $20 \%$ of the TH-immunoreactive cells corresponding to the dorsal A10 cell group (A10d; Hökfelt et al., 1984), lying along the base of the cerebral aqueduct, were doubly labeled. This labeling was detected over the small TH-immunoreactive cells in the dorsal mesencephalic raphe region, and not over the larger multipolar cells of the A11 cell group lying dorsolateral to the $\mathrm{A} 10 \mathrm{~d}$ cell group. No significant labeling was detected over serotonin-immunoreactive cells of the raphe nuclei (data not shown).

Diencephalic dopaminergic cells. In the diencephalon, DAT mRNA-containing neurons were found in regions corresponding to the $\mathrm{A} 12$ and $\mathrm{A} 13$ dopaminergic cell groups (Fig. $2 A-D$ ). 


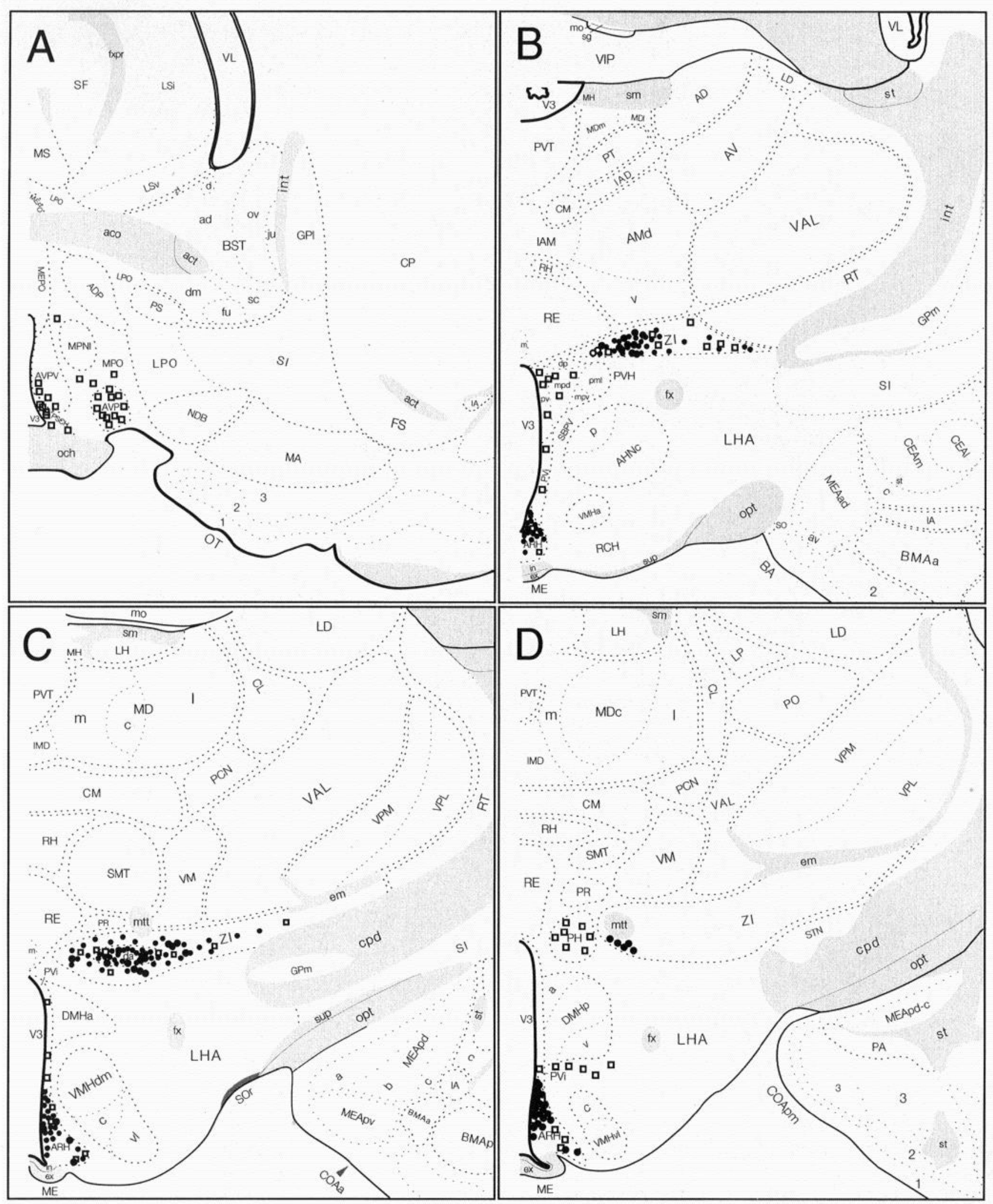

Figure 2. Expression of DAT and NET mRNA in catecholaminergic neurons. A series of line drawings adapted from Swanson (1992) arranged from rostral $(A)$ to caudal $(L)$ through the diencephalon, mesencephalon, and brainstem illustrate the number and location of catecholaminergic neurons that contain DAT or NET mRNA labeling. $A-H$, Open squares mark the locations of TH-immunoreactive cell bodies in the diencephalon and mesencephalon, and open circles denote DAT mRNA-containing cells that were not immunolabeled. Solid circles indicate doubly labeled (THimmunoreactive, DAT mRNA-containing) neurons. $I-L$, In the brainstem, the locations of DBH-immunoreactive neurons that lack NET mRNA labeling are indicated as open triangles, and solid triangles denote doubly labeled (DBH-immunoreactive, NET mRNA-containing) neurons. The density of cells in each drawing is approximately that seen in a single $20-\mu$ m-thick section. 


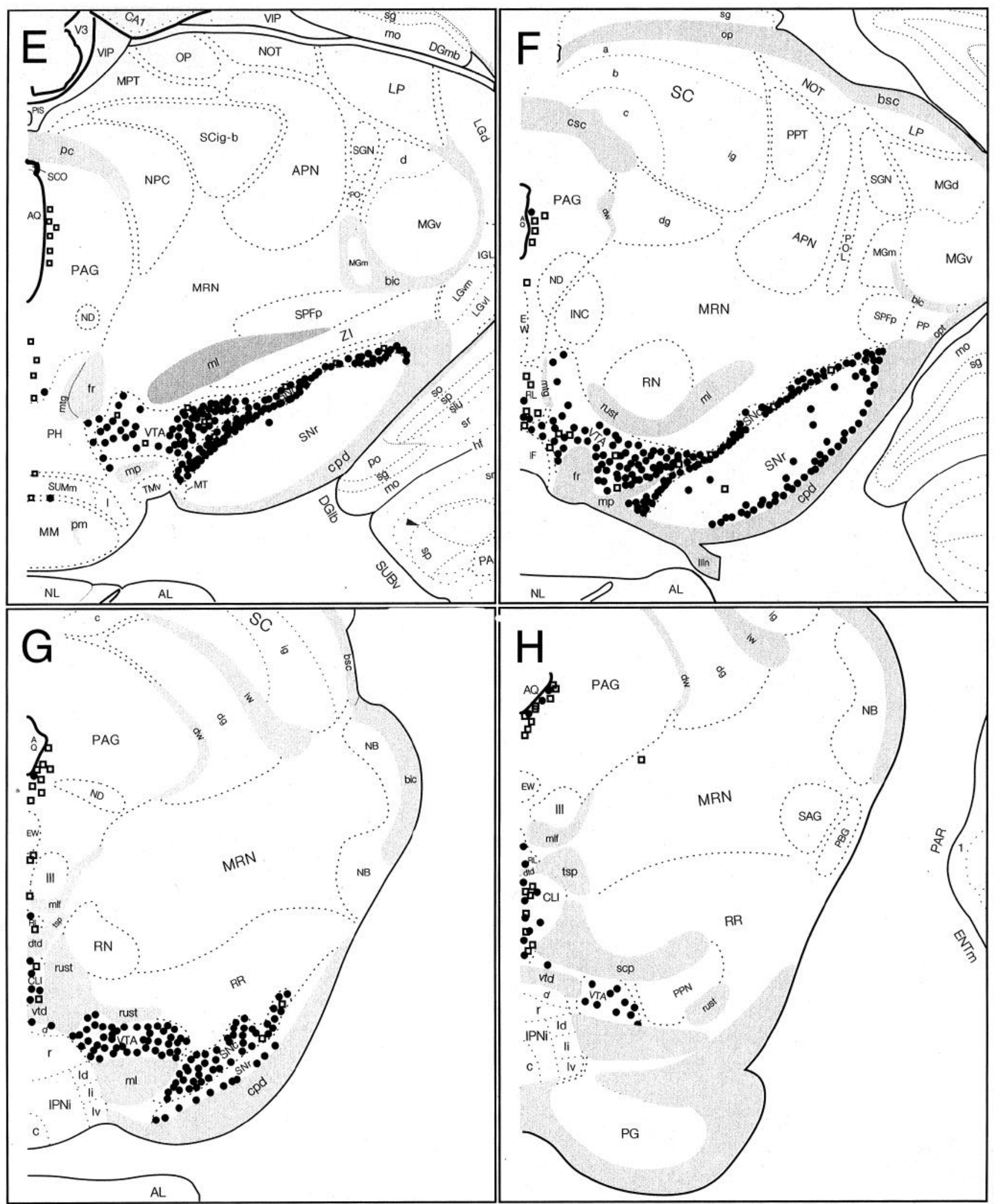

Figure 2. Continued.

The most intensely labeled DAT mRNA-containing cells, which presumably belong to the A13 cell group, were found in the zona incerta; moderate levels of labeling were found over neurons in the arcuate nucleus (A12 cell group). As was the case for mesencephalic dopaminergic cells, greater than $90 \%$ of THimmunoreactive neurons in the medial part of the zona incerta and arcuate nucleus showed at least moderate levels of DAT mRNA labeling. Surprisingly, no significant labeling was de- 


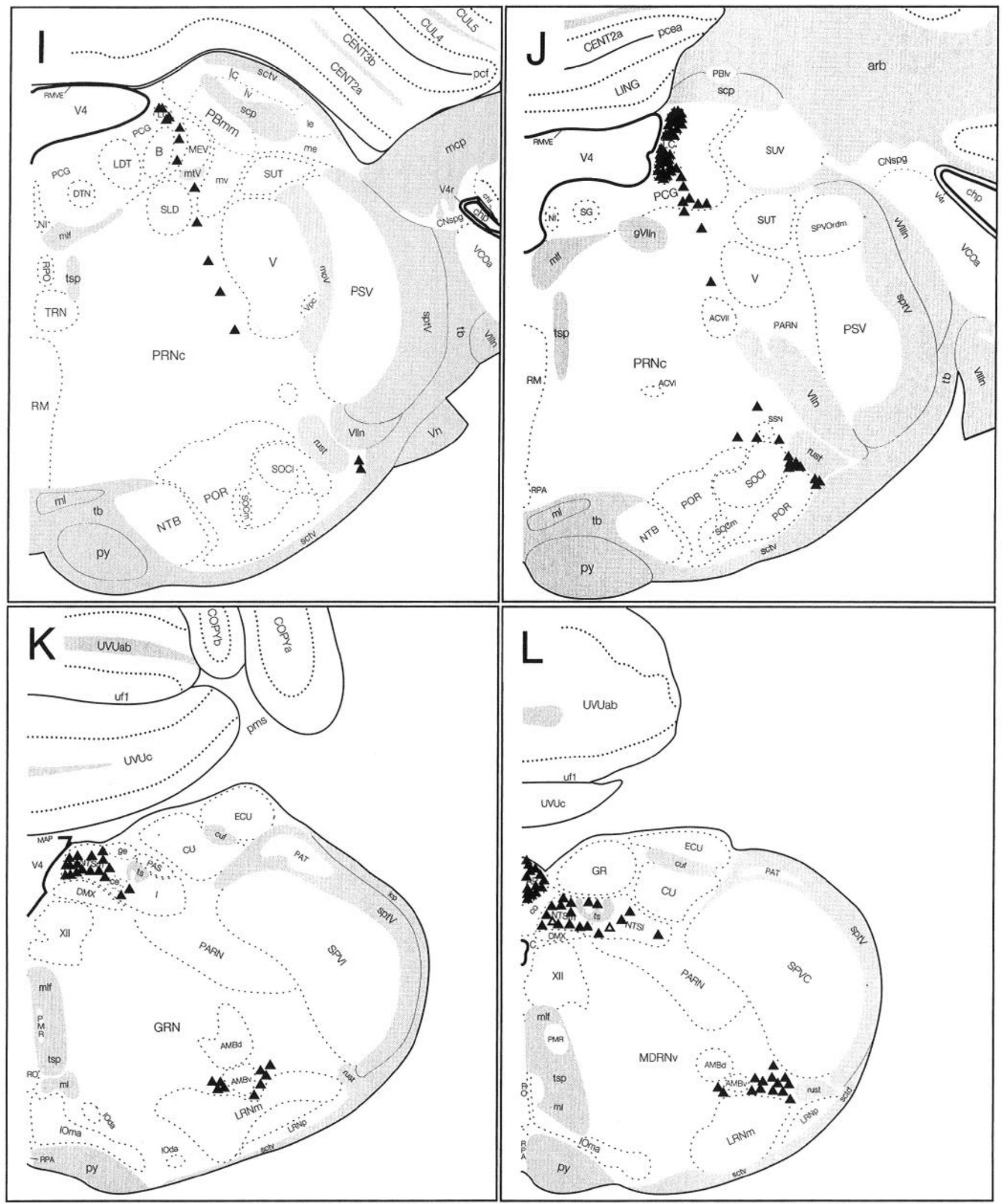

Figure 2. Continued.

tected in regions of the $\mathrm{A} 11, \mathrm{~A} 14$, and $\mathrm{A} 15$ catecholaminergic cell groups, which include the dopaminergic neurons in the preoptic part of the periventricular zone of the hypothalamus (Fig. 2A). Nor were doubly labeled neurons found in the an- teroventral periventricular nucleus of the hypothalamus, the suprachiasmatic preoptic nucleus, or anteroventral preoptic nucleus. Similarly, no significant labeling for DAT mRNA was observed over TH-immunoreactive cells in the All cell group, 


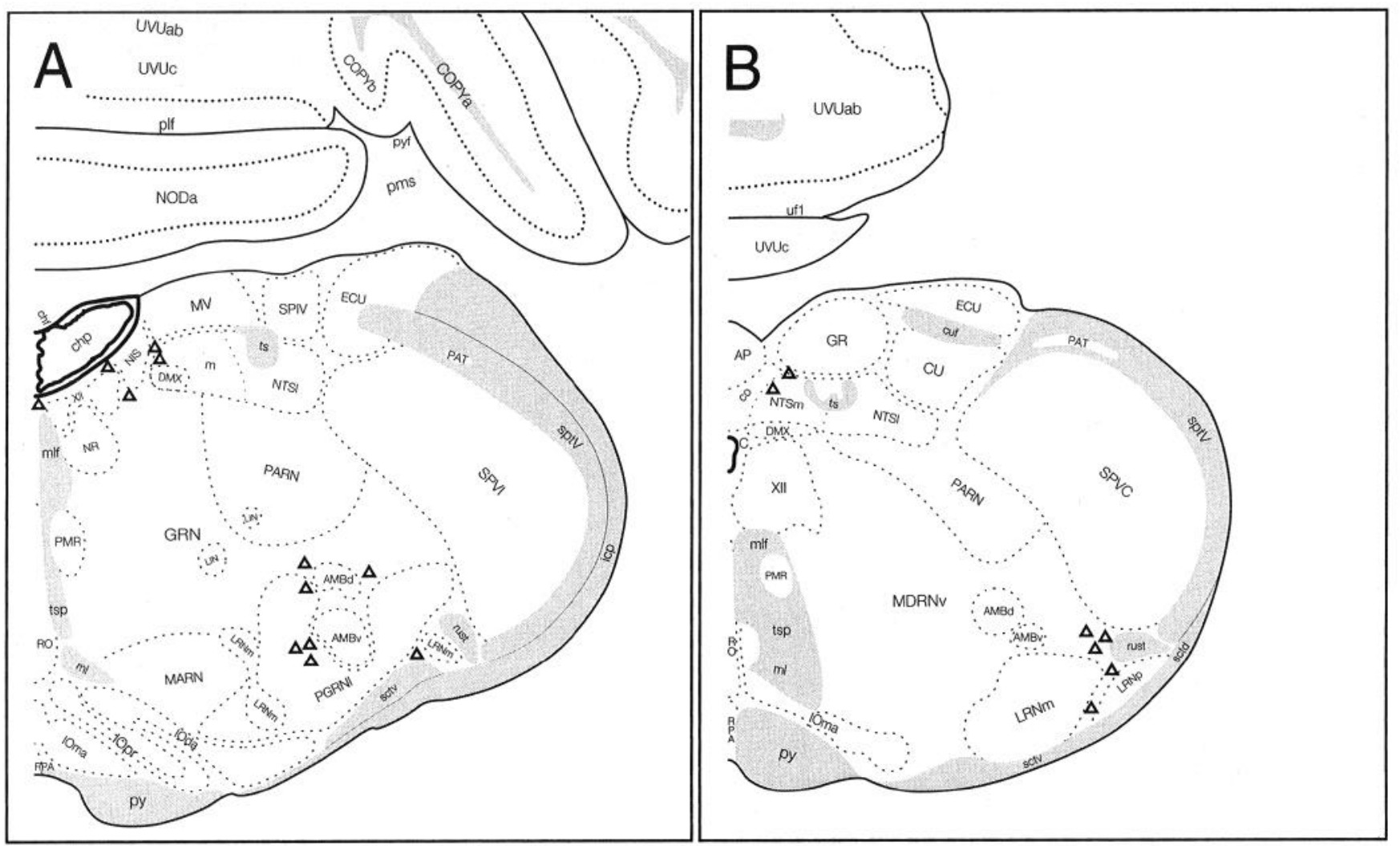

Figure 3. Lack of NET mRNA in PNMT-immunoreactive cell bodies $(\Delta)$ in the brainstem. Line drawings adapted from Swanson (1992) that illustrate the density and distribution of PNMT-immunoreactive neurons in the $\mathrm{C} 1$ and $\mathrm{C} 2$ regions in sections processed for both immunohistochemistry and in situ hybridization. Despite a few NET mRNA-containing neurons in the region of the $\mathrm{Cl}$ and $\mathrm{C} 2 \mathrm{cell}$ groups, no doubly labeled neurons were identified.

which lies primarily in the posterior hypothalamus and extends into the periaqueductal gray.

Olfactory bulb. Moderate levels of DAT mRNA labeling were detected over periglomerular cells of the olfactory bulb. These cells correspond to the A16 catecholaminergic cell group and have short axons that participate in local circuits within olfactory glomeruli (Björklund and Lindvall, 1984). Greater than $90 \%$ of the $\mathrm{TH}$-immunoreactive cells in this cell group were doubly labeled for DAT mRNA.

Brainstem noradrenergic cells. NET mRNA labeling was detected exclusively over neurons of the medulla oblongata and pons in regions that correspond to the A4, A5, A6, and A7 catecholaminergic cell groups, as well as over neurons in the lateral tegmentum and nucleus of the solitary tract that correspond to the locations of $\mathrm{A} 1$ and $\mathrm{A} 2$ catecholaminergic neurons (Fig. 2I-L). The locus coeruleus (A6 cell group) contained the greatest density of heavily labeled NET mRNA-containing cells, but intensely labeled neurons were also found rostral to the locus coeruleus, adjacent to the nucleus of the lateral lemniscus (A7 cell group) (Fig. 5A). Additional NET mRNA-containing neurons were distributed along the medial border of the motor nucleus of the trigeminal nerve, as well as between the lateral superior olivary complex and the rubrospinal tract (A5 cell group). Dense NET mRNA labeling was observed over neurons located caudal to the locus coeruleus in the lateral part of the roof of the fourth ventricle (A4 cell group). In contrast, only moderate levels of NET mRNA labeling were detected over neurons in the $\mathrm{A} 1$ and $\mathrm{A} 2$ cell groups. A combined immuno- histochemical/in situ hybridization analysis of NET mRNA in catecholaminergic neurons revealed that an overwhelming majority of DBH-immunoreactive cells in the A1-A7 cell groups were doubly labeled for NET mRNA. Figure 5 depicts the distribution of DBH-immunoreactive cells, NET mRNA-containing cells, and doubly labeled cells in the A5, A6, and A7 cell groups. Greater than $90 \%$ of the DBH-immunoreactive cells in the A4, A5, A6, and A7 cell groups contained dense NET mRNA labeling. Similarly, $90 \%$ of the DBH-immunoreactive cells in the A1 cell group and $85 \%$ of those in the A 2 cell group were doubly labeled. However, the intensity of labeling for NET mRNA over cells in the A1 and A2 cell groups was somewhat lower relative to the other noradrenergic cell groups. In addition, greater than $90 \%$ of the DBH-immunoreactive cells in the area postrema (A2 cell group) showed at least moderate levels of labeling for NET mRNA.

Brainstem adrenergic cells. Several NET mRNA-containing neurons were found in brainstem regions that contain adrenergic cell bodies (Fig. $3 A, B$ ). These regions are known to contain the $\mathrm{C} 1$ and C2 catecholaminergic cell groups (Hökfelt et al., 1974, 1984; Swanson et al., 1978; Ruggiero et al., 1985), which lie rostral to, but partially overlap, the distribution of the Al and A2 noradrenergic cell groups. Although a significant number of PNMT-immunoreactive neurons were detected in the regions of the $\mathrm{C} 1$ and $\mathrm{C} 2$ adrenergic cell groups, and the distribution of these cells corresponded to previously published maps, in no case did NET mRNA labeling exceed background over PNMTimmunoreactive cells. 

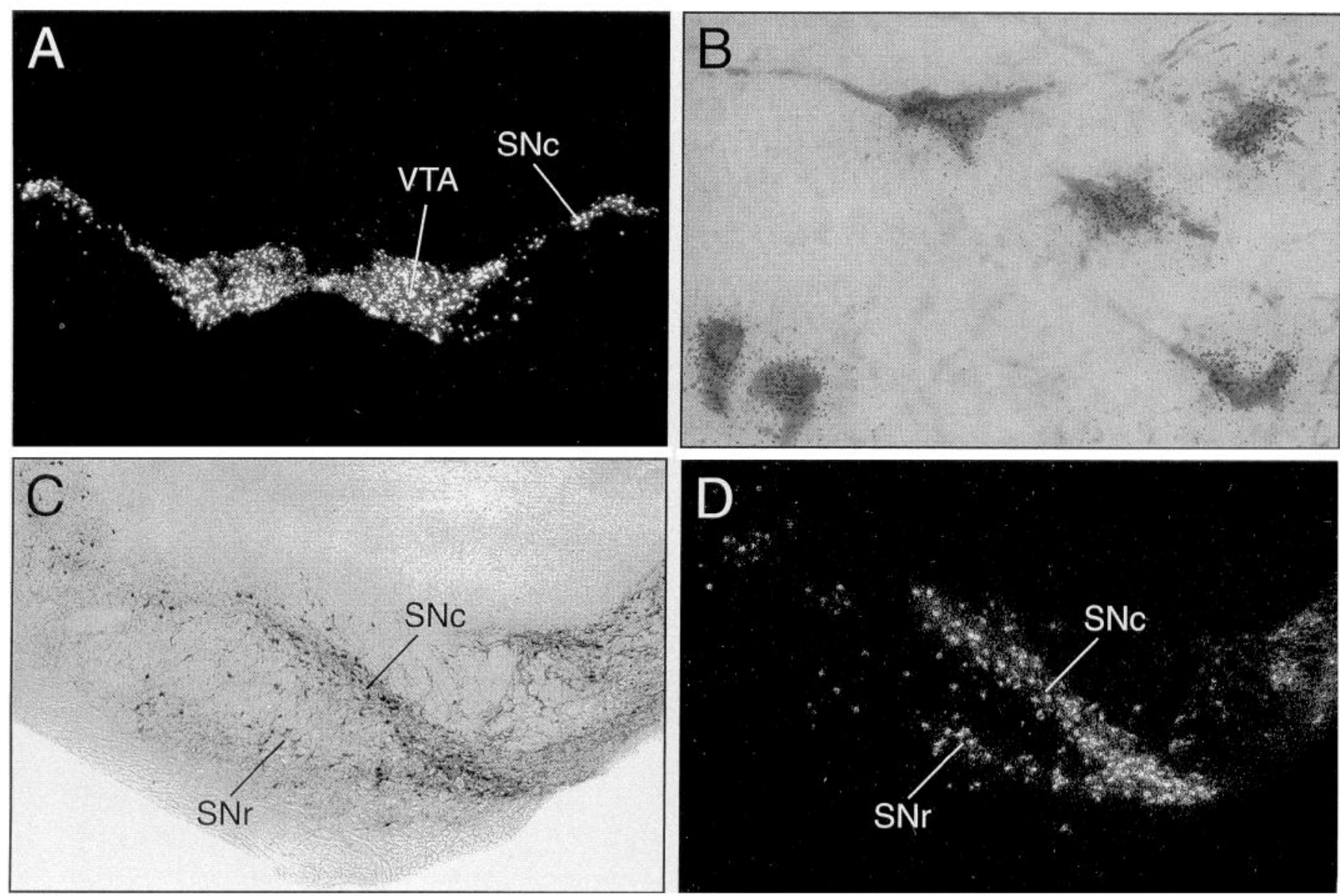

Figure 4. DAT mRNA labeling over TH-immunoreactive neurons in the substantia nigra and ventral tegmental area. $A$, Dark-field photomicrograph of DAT mRNA-containing neurons in the ventral tegmental area and substantia nigra $(1.6 \times)$. $B$, Doubly labeled neurons in the ventral tegmental area to illustrate the density of silver grains overlying TH-containing neurons visualized by immunohistochemistry $(50 \times)$. $C$ and $D, B$ right-field and dark-field photomicrographs of the same field that show the appearance and distribution of TH immunoreactivity $(C)$ and DAT mRNAcontaining $(D)$ neurons in the ventral tegmental area and substantia nigra $(4 \times)$. VTA, ventral tegmental area; $S N$, substantia nigra.

\section{Discussion}

The main conclusion to be drawn from the findings presented here is that DAT and NET are expressed only in catecholaminergic neurons with a considerable degree of cell-type specificity. NET mRNA labeling was found only in regions of the medulla oblongata and pons known to contain noradrenergic cell bodies, and no evidence for NET mRNA in dopaminergic neurons was observed even though NET has a higher affinity for dopamine than norepinephrine (Snyder, 1970; Pacholcyzk et al., 1991). Moreover, despite the assumption that the NET serves as the transporter for adrenaline, we were unable to detect NET mRNA in PNMT-immunoreactive neurons. Noradrenergic neurons do not appear to express DAT mRNA, which is restricted to dopaminergic neurons in the mesencephalon and diencephalon. However, among dopaminergic neurons of the hypothalamus, only the A1 2 cells in the arcuate nucleus appear to express detectable levels of DAT mRNA.

$D A T$ mRNA expression in dopaminergic neurons. The present study confirms that DAT in the rat brain is encoded by a single mRNA that is approximately $3.8 \mathrm{~kb}$ in size, and that the DAT mRNA is expressed by neurons that comprise both the mesostriatal and mesocorticolimbic dopaminergic pathways. Thus, neurons that send projections to the ventral and dorsal striatum appear to express the same DAT mRNA as do neurons that project to limbic regions, isocortex, and the spinal cord. A degree of molccular heterogeneity has been observed for the DAT in these dopaminergic pathways and it has been proposed that differential phosphorylation or glycosylation of the DAT may account for slight differences in the molecular weight of the transporter in the nucleus accumbens and the striatum (Lew et al., 1991). Our results support such a post-translational mechanism and indicate that a single transcript encodes the DAT in dopaminergic neurons.

Intense labeling for DAT mRNA was found over dopaminergic neurons in the zona incerta (A13 cell group), but in contrast to the uniform pattern of DAT mRNA expression in the mesencephalic dopaminergic neurons, DAT mRNA does not appear to be expressed in all hypothalamic dopaminergic cell groups. Moderate levels of DAT mRNA are expressed in the dopaminergic neurons of the arcuate nucleus (A12 cell group), which contribute to the tuberinfundibular pathway and send projections within the hypothalamus to the periventricular, dorsomedial, anterior, and ventromedial hypothalamic nuclei, as well as project to extrahypothalamic sites such as the amygdala and spinal cord (Bodoky and Rethely, 1977; Björklund and Skagerberg, 1979; Blessing and Chalmers, 1979; Krieger et al., 1979; Zaborszky and Makara, 1979; Swanson et al., 1981; Za- 

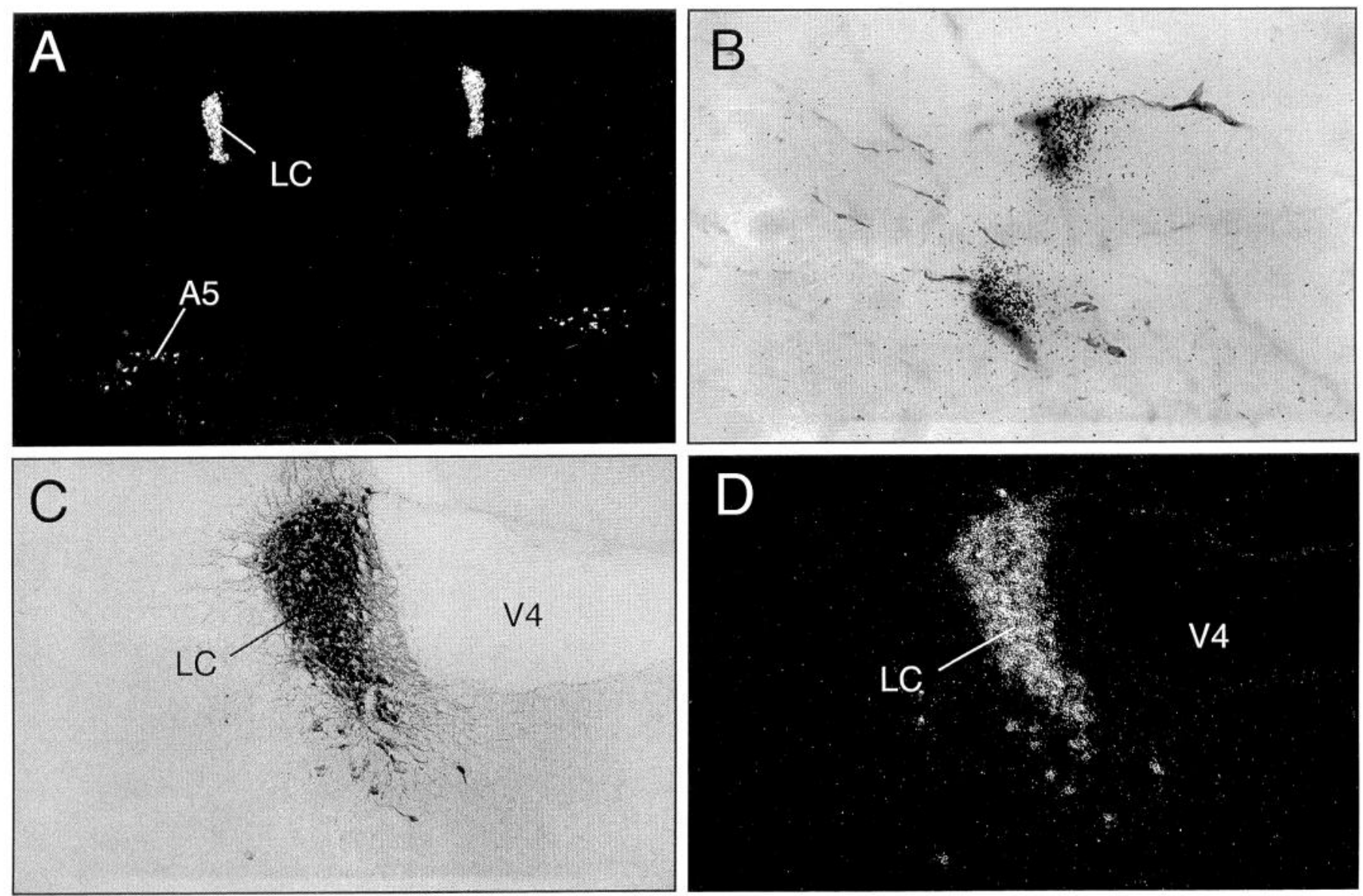

Figure 5. NET mRNA expression in DBH-immunoreactive neurons. $A$, Dark-field photomicrograph of NET mRNA-containing neurons in the locus coeruleus $(1.6 \times), B$, Doubly labeled neurons in the $\mathrm{A} 7$ group illustrate the density of silver grains overlying DBH-immunoreactive neurons $(50 \times)$. $C$ and $D$, Bright-field and dark-field photomicrographs of the same field that show the appearance and distribution of DBH-immunoreactive $(C)$ and NET mRNA-containing $(D)$ neurons in the locus coeruleus $(6.6 \times), L C$, locus coeruleus.

borszky, 1982; Skagerberg and Lindvall, 1985). Thus, DAT is likely to act at these terminal fields to regulate dopaminergic neurotransmission in accordance with the observation of highaffinity dopamine uptake in the hypothalamus (George and VanLoon, 1982). Although a previous study has reported very low levels of DAT mRNA expression in the region of the arcuate nucleus (Cerruti et al., 1993), labeling in the zona incerta, which contains much higher levels of DAT mRNA, has not been reported.

Dopaminergic neurons in the preoptic area, periventricular nuclei, and the posterior hypothalamus do not appear to express DAT mRNA. These dopaminergic cells include those of the periventricular hypothalamic nuclei (A14 cell group), the anteroventral periventricular hypothalamic nucleus and the suprachiasmatic preoptic nucleus (A14 cell group), the anteroventral preoptic nucleus (A15 cell group), and the posterior hypothalamus (A11 cell group). Although a previous study reported DAT mRNA expression in the region of the All cell group (Cerruti et al., 1993), using the combined immunohistochemistry/in situ hybridization method we were able to demonstrate directly specific labeling for DAT mRNA only in the adjacent dorsal A10 cell group and not in the A11 cell group.

The absence of DAT mRNA expression in these cells suggests that the dopamine released by their terminals does not undergo rapid inactivation by reuptake into presynaptic cells. One pos- sible interpretation of this finding is that dopamine produced by these cell groups functions as an endocrine regulator acting on local neurons, or perhaps exerts long-lasting influences on postsynaptic cells. Interestingly, some of the dopaminergic cell bodies that lack DAT mRNA expression are regulated by circulating gonadal steroids. For example, dopaminergic neurons in the AVPv are sexually dimorphic and the expression of TH in these cells is regulated by gonadal steroid hormones (Simerly, 1989). The absence of DAT mRNA labeling in the dopaminergic cells of the AVPv may therefore be the result of transcriptional downregulation of DAT by steroid hormones.

NET $m R N A$ expression in noradrenergic neurons. NET $\mathrm{mRNA}$ appears to be expressed in the majority of neurons in each of the noradrenergic cell groups of the rat brain. The results of our combined immunohistochemistry/in situ hybridization studies indicate that NET expression is localized exclusively to the DBHimmunoreactive cell bodies of the medulla oblongata and the pons. NET mRNA was also detected in the area postrema, a circumventricular organ that lies next to the fourth ventricle and is thought to function as an emetic chemoreceptor (Van der Kooy and Koda, 1983). NET is most abundantly expressed in the locus coeruleus, which is the source of noradrenergic afferents to the entire isocortex, and also supplies inputs to the thalamus, optic tectum, and cerebellum. NET mRNA labeling was also detected in the medullary $\mathrm{A} 1$ and $\mathrm{A} 2$ cell groups, which 
provide noradrenergic innervation to the hypothalamus, preoptic area, and basal forebrain (Ricardo and Koh, 1978; Swanson et al., 1981; McKellar and Loewy, 1982; Sawchenko and Swanson, 1982; Cunningham and Sawchenko, 1988). The expression of NET in noradrenergic pathways to the hypothalamus implies a role for the transporter in regulating endocrine and autonomic responses. For example, changes in the expression of NET in medullary A1 neurons that project to the magnocellular division of the paraventricular hypothalamus and supraoptic nucleus may influence noradrenergic regulation of the magnocellular neurons in the PVN and SO that are critical for fluid and cardiovascular homeostasis (Reis, 1984, 1986; Ciriello et al., 1986). Similarly, altered expression of the NET in the A6 and A2 noradrenergic neurons that innervate hypothalamic regions that regulate hormone secretion from the anterior pituitary, such as the paraventricular or arcuate nuclei (Cunningham and Sawchenko, 1988; Swanson, 1988), may have a profound influence on neuroendocrine function.

The $\mathrm{C} 1$ and $\mathrm{C} 2$ adrenergic cell groups in the medulla oblongata were examined for the presence of NET and DAT mRNA labeling by in situ hybridization since epinephrine is a substrate for both the norepinephrine transporter $\left(K_{\mathrm{m}}=3 \mu \mathrm{M}\right)$ and the dopamine transporter $\left(K_{\mathrm{m}}=5 \mu \mathrm{M}\right)$ (Kilty and Amara, unpublished observations). Our results, however, indicate that neither DAT nor NET mRNA is expressed in adrenergic neurons. Although there is controversy in the literature over the role of epinephrine as a neurotransmitter in the CNS, immunocytochemical, biochemical, and electrophysiological studies have demonstrated that these adrenergic cells send projections primarily to the hypothalamus, and appear to be involved in cardiovascular homeostasis (Hökfelt et al., 1974, 1984; Swanson et al., 1978; Moore and Bloom, 1979; Ruggiero et al., 1985; Tucker et al., 1987). If epinephrine functions as a neurotransmitter in these neurons, our results suggest the presence of a separate and specific transport system that terminates adrenergic neurotransmission. Alternatively, it is possible that epinephrine may utilize a mechanism of synaptic transmission that is distinct from the other hioactive amines, or may act as an endocrine regulator that does not require rapid reuptake mechanisms.

In summary, the cell-type-specific expression pattern of catecholamine transporters suggests that DAT and NET gene expression may be closely linked to cellular mechanisms that specify transmitter phenotype. Thus, the DAT appears to be expressed only in dopaminergic neurons and expression of the NET is restricted to noradrenergic cells. Whether epinephrine uptake is mediated by yet a third transporter or is affected by a distinct transport system remains to be determined. Nevertheless, it is clear that despite marked similarities in their primary structures and shared pharmacological properties, the nonoverlapping expression patterns of the DAT and NET mean that these important molecules function independently in distinct functional ncuronal pathways. Moreover, the possibility that the expression or activity of each transporter is differentially regulated in these pathways provides a possible basis for understanding how pharmacological agents that act on both transporters exert such diverse effects on neurological events mediated by catecholaminergic neurotransmission.

\section{References}

Andersen PH (1987) Biochemical and pharmacological characterization of [3H]GBR-12935 binding in vitro to rat striatal membranes: labeling of the dopamine uptake complex. J Neurochem 48:18871890 .

Andersen PH (1989) The dopamine uptake inhibitor GBR 12909: selectivity and molecular mechanisms of action. Eur $\mathbf{J}$ Pharmacol 166:493-504.

Arnold AP (1980) Quantitative analysis of sex differences in hormone accumulation in the Zebra Finch brain: methodological and theoretical issues. J Comp Neurol 189:421-436.

Bannon MJ, Poosch MS, Xia Y, Goebel DJ, Cassin B, Kapatos G (1992) Dopamine transporter mRNA content in human substantia nigra decreases precipitously with age. Proc Natl Acad Sci USA 89: 7095-7099.

Björklund A, Lindvall O (1984) Dopamine-containing systems in the CNS. In: Handbook of chemical neuroanatomy, Vol 2, Classical transmitters in the CNS, Pt 1 (Bjorklund A, Hokfelt T, eds), pp 55-122. New York: Elsevier.

Björklund A, Lindvall O (1986) Catecholaminergic brain stem regulatory systems. In: Handbook of physiology, Sec 1, The nervous system (Mountcastle, Bloom, Geirger, eds), pp 155-235. New York: American Physiology Society.

Björklund A, Skagerberg G (1979) Evidence for a major spinal cord projection from the diencephalic All dopamine cell group in the rat using transmitter-specific fluorescent retrograde tracing. Brain Res 177:170-175.

Blakely RD, Berson HE, Fremeau RT, Caron MG, Peck MM, Prince HK, Bradly CC (1991) Cloning and expression of a functional serotonin transporter from rat brain. Nature 354:66-70.

Blessing WW, Chalmers JP (1979) Direct projection of catecholamine (presumably dopamine)-containing neurons from hypothalamus to spinal cord. Neurosci Lett 11:35-40.

Bloom FE, Schulman JA, Koob GF (1989) Catecholamines and behavior. In: Handbook of experimental pharmacology, pp 27-88. New York: Elsevier.

Bodoky M, Réthelyí M (1977) Dendritic arborization and axon trajectory of neurons in the hypothalamic arcuate nucleus of the rat. Exp Brain Res 28:543-555.

Carter DA, Fibiger HC (1977) Ascending projections of presumed dopamine-containing neurons in the ventral tegmentum of the rat as demonstrated by horseradish peroxidase. Neuroscience 2:569-576.

Cerruti C, Walther DM, Kuhar MJ, Uhl GR (1993) Dopamine transporter mRNA expression is intense in rat midbrain neurons and modest outside midbrain. Mol Brain Res 18:181-186.

Ciriello J, Caverson MM, Polosa C (1986) Function of the ventrolateral medulla in the control of the circulation. Brain Res Rev 11:359391

Cooper JR, Bloom FE, Roth RH (1991) The biochemical basis of neuropharmacology, 6th ed. New York: Oxford UP.

Cox KH, Deleon DV, Angerer LM, Angerer RC (1984) Detection of mRNAs in sea urchin embryos by in situ hybridization using asymmetric RNA probes. Dev Biol 101:485-502.

Crow TJ (1982) The biology of schizophrenia. Experientia 38:12751282

Cunningham ET, Sawchenko PE (1988) Anatomical specificity of noradrenergic inputs to the paraventricular and supraoptic nuclei of the rat hypothalamus. J Comp Neurol 274:60-76.

Fallon JH, Moore RY (1978) Catecholamine innervation of the basal forebrain. IV. Topography of dopamine projection to the basal forebrain and neostriatum. J Comp Neurol 180:545-580.

Gann DS, Ward DG, Carlson DE (1978) Neural control of ACTH: a homeostatic reflex. Recent Prog Horm Res 34:357-400.

George SR, VanLoon GR (1982) Characterization of high affinity dopamine transport into the dopamine neurons of the hypothalamus. Brain Res 234:339-355.

Giros B, Mestikawy SE, Bertrand L, Caron M G (1991) Cloning and functional characterization of a cocaine-sensitive dopamine transporter. FEBS Lett 295:149-154.

Glowinski J, Axelrod J (1964) Inhibition of uptake of tritiated noradrenaline in the intact rat brain by imipramine and structurally related compounds. Nature 204:1318.

Hoffman BJ, Mexby E, Brownstein MJ (1991) Cloning of a serotonin transporter affected by antidepressants. Science 254:79-80.

Hökfelt T, Fuxe K, Goldstein M, Johansson O (1974) Immunohistochemical evidence for the existence of adrenaline neurons in the rat brain. Brain Res 66:235-251.

Hökfelt T, Johansson O, Goldstein M (1984a) Central catecholamine 
neurons as revealed by immunohistochemistry with special reference to adrenaline neurons. In: Handbook of chemical neuroanatomy, Vol II, Classical transmitters in the CNS, Pt 2 (Björklund A, Hökfelt T, eds), pp 157-276. New York: Elsevier.

Hökfelt T, Mårtensson R, Björklund A, Kleinau S, Goldstein M (1984b) Distributional maps of tyrosine-hydroxylase-immunoreactive neurons in the rat brain. In: Handbook of chemical neuroanatomy, Vol II, Classical transmitters in the CNS, Pt 1 (Björklund A, Hökfelt $T$, eds), pp 277-379. New York: Elsevier.

Hornykiewicz O (1973) Parkinson's disease: from brain homogenate to treatment. Fed Proc 32:183-190.

Iversen LL (1973) Monoamines in the mammalian central nervous system and the actions of antideprcssant drugs. Biochem Soc Spcc Publ 1:81-96.

Iversen LL (1977) Uptake processes for biogenic amines. In: Handbook of psychopharmacology (Iverson C, Iverson SD, Snyder SH, eds), pp 381-442. New York: Plenum.

Janowsky AA, Berger P, Vocci F, Labarca R, Skolnick P, Paul SM (1986) Characterization of sodium-dependent [3H]GBR-1295 binding in brain: a radioligand for selective labeling of dopamine transporter complex. I Neurochem 46:1272-1276.

Javitch JA, Blaustein RO, Snyder SH (1983) [3H]mazindol binding associated with neuronal dopamine uptake sites in corpus striatum membranes. Eur J Pharmacol 90:461-462.

Kilty JE, Lorang D, Amara SG (1991) Cloning and expression of a cocaine-sensitive rat dopamine transporter. Science 254:578-579.

Krieger MS, Conrad LCA, PfaffDW (1979) An autoradiographic study of the efferent connections of the ventromedial nucleus of the hypothalamus. J Comp Neurol 183:785-816.

Lechan RM, Nestler JL, Jackson S (1982) The tuberoinfundibular system of the rat as demonstrated by immunohistochemical localization of retrogradely transported wheat germ agglutinin (WGA) from the median eminence. Brain Res 245:1-15.

Lew R, Grigoriadis, Wilson A, Boja JW, Simantov R, Kuhar MJ (1991) Dopamine transporter: glycosylation with exo- and endoglycosidases. Brain Res 539:239-246.

Matthysee S (1973) Antipsychotic drug actions: a clue to the neuropathology of schizophrenia? Fed Proc 32:200-205.

McKellar S, Loewy AD (1982) Efferent projections of the Al catecholamine cell group in the rat: an autoradiographic study. Brain Res 241:11-29.

Meltzer HY (1980) Relevance of dopamine autoreceptors for psychiatry: preclinical and clinical studies. Schizophr Bull 6:456-475.

Meltzer HY, Stahl SM (1976) The dopamine hypothesis of schizophrenia: a review. Schizophr Bull 2:19-76.

Moore RY, Bloom FE (1979) Central catecholamine neuron systems: anatomy and physiology of the norepinephrine and epinephrine systems. Annu Rev Neurosci 2:113-68.

Moore RY, Card JP (1984) Noradrenaline-containing neuron systems. In: Handbook of chemical neuroanatomy, Vol II, Classical transmitters in the CNS, Pt I (Björklund A, Hökfelt T, eds), pp 123-156. New York: Elsevier.

Pacholczyk T, Blakely RD, Amara SG (1991) Expression cloning of a cocaine- and antidepressant-sensitive human noradrenaline transporter. Nature 350:350-354.

Ramamoorthy S, Prasad PD, Kulanthaivel P, Leibach FH, Blakely RD, Ganapathy V (1993) Expression of a cocaine-sensitive norepinephrine transporter in the human placental syncytiotrophoblast. Biochemistry 32:1346-1353.

Reis DJ (1986) The Cl area of rostral ventrolateral medulla: role in tonic and reflex regulation of arterial pressure. In: Central and peripheral mechanisms of cardiovascular regulation (Magro A, Osswald W, Reis D, Vanhoutte P, eds), pp 487-502. New York: Plenum.

Reis DJ, Ross CA, Ruggiero DA, Granata AR, Joh TH (1984) Role of adrenaline neurons of ventrolateral medulla (the $\mathrm{Cl}$ group) and the tonic and phasic control of arterial pressure. Clin Exp Hypertens $6: 221-242$.

Ricardo JA, Koh ET (1978) Anatomical evidence of direct projections from the nucleus of the solitary tract to the hypothalamus, anygdala, and other forebrain structures in the rat. Brain Res 153:1-26.
Ritz MC, Lamb RJ, Goldberg SR, Kuhar MJ (1987) Cocaine receptors on dopamine transporters are related to self-administration of cocaine. Science 237:1219-1223.

Ruggiero DA, Ross CA, Anwar M, Park DH, Tong HJ, Reis DJ (1985) Distribution of neurons containing phenylethanolamine $N$-methyltransferase in medulla and hypothalamus of rat. J Comp Neurol 239: $127-154$.

Sawchenko PE, Swanson LW (1982) The organization of noradrenergic pathways from the brainstem to the paraventricular and supraoptic nuclei in the rat. Brain Res 257:275-325.

Seeman P (1980) Brain dopamine receptors. Pharmacol Rev 32:229313.

Sccman $P$ (1987) Dopamine receptors and the dopamine hypothesis of schizophrenia. Synapse 1:133-152.

Shimada S, Kitayama S, Lin C, Patel A, Nanthakumar E, Gregpr P, Kuhar M, Uhl G (1991) Cloning and expression of a cocaine-sensitive dopamine transporter complementary DNA. Science 254:576578 .

Shimada S, Kitayama S, Walther D, Uhl G (1992) Dopamine transporter mRNA: dense expression in ventral midbrain neurons. Mol Brain Res 13:359-362.

Simerly RB (1989) Hormonal control of the development and regulation of tyrosine hydroxylase expression within a sexually dimorphic population of dopaminergic cells in the hypothalamus. Mol Brain Res $6: 297-310$.

Skagerberg G, Lindvall O (1985) Organization of diencephalic dopamine neurons projecting to the spinal cord in the rat. Brain Res 342:340-351

Snyder SH (1970) Putative neurotransmitters in the brain; selective neuronal uptake, subcellular localization, and interactions with centrally acting drugs. Biol Psychiatry 2:367-389.

Snyder SH (1972) Catecholamines in the brain as mediators of amphetamine psychosis. Arch Gen Psychiatry 27:169-179.

Snyder SH (1973) Amphetamine psychosis: a "model" of schizophrenia mediated by catecholamines. Am J Psychiatry 130:61-67.

Swanson LW (1982) The projections of the ventral tegmental area and adjacent regions: a combined fluorescent retrograde tracer and immunofluorescence study in the rat. Brain Res Bull 9:321-353.

Swanson LW (1992) Brain maps: structure of the rat brain. Amsterdam: Elsevier.

Swanson LW, Connelly MA, Hartman BK (1978) Further studies on the fine structure of the adrenergic innervation of the hypothalamus. Brain Res 151:165-174.

Swanson LW, Sawchenko PE, Berod A, Hartman BK, Helle KB, Vanorden DE (1981) An immunohistochemical study of the organization of catecholaminergic cells and terminal fields in the paraventricular and supraoptic nuclei of the hypothalamus. J Comp Neurol 196:271-185.

Tucker DA, Saper CB, Ruggiero DA, Reis DI (1987) Organization of central adrenergic pathways: I. Relationships of ventrolateral medullary projections to the hypothalamus and spinal cord. J Comp Neurol 259:591-603.

Usdin TB, Mezey E, Chen C, Brownstein MJ, Hoffman BJ (1991) Cloning of the cocaine-sensitive bovine dopamine transporter. Proc Natl Acad Sci USA 88:11168-11171.

Van der Kooy D, Koda LY (1983) Organization of the projections of a circumventricular organ: the area postrema in the rat. $J$ Comp Neurol 219:328-338.

Watts AG, Swanson LW (1989) Combination of in situ hybridization with immunohistochemistry and retrograde tract-tracing. Methods Neurosci 1:127-136.

Zaborszky L (1982) Afferent connections of the medial basal hypothalamus. In: Advances in anatomy embryology and cell biology, Vol 69 (Hild W, Van Limborgh J, Ortman R, Pauly JE, Schiebler TH, eds), pp 1-107. New York: Springer.

Zaborszky L, Makara GB (1979) Intrahypothalamic connections: an electron microscopic study in the rat. Exp Brain Res 34:201-215. 